Article

\title{
The Role of a Manager's Intangible Capabilities in Resource Acquisition and Sustainable Competitive Performance
}

\author{
Qianwei Ying ${ }^{1}$, Hazrat Hassan ${ }^{1, *}$ and Habib Ahmad ${ }^{2}$ (1) \\ 1 Business School, Sichuan University, Chengdu 610065, China; yingqw@scu.edu.cn \\ 2 Hamdard Institute of Management Sciences, Hamdard University, Karachi 74600, Pakistan; \\ tumharahabib@gmail.com \\ * Correspondence: hassan2018@stu.scu.edu.cn; Tel.: +86-132-1906-9552
}

Received: 26 December 2018; Accepted: 17 January 2019; Published: 19 January 2019

check for updates

\begin{abstract}
The answer to the challenging question, "Should one either invest in tangible resources or intangible resources/capabilities?" is still fragmented. In prior studies, more emphasis is given to tangible resources, while intangible resources have comparatively received minor attention, despite their significant role in the success of small and medium enterprises (SMEs). Particularly the role of the intangible skills; intellectual capital, financial literacy (FL), and business experience (BE) in resource acquisition and sustainable competitive performance has missed in prior studies. Grounded on the resource-based view and upper echelon theory, this study examines the role of intellectual capital in sustainable competitive performance with a mediating role of resource acquisition. This research also assesses the moderating role of financial literacy and business experience between intellectual capital and resource acquisition. Data are collected through structured questionnaires from 384 owners/managers of Pakistani SMEs. After analyzing the data through structural equation modeling (SEM), the results indicate that intellectual capital helps managers in acquiring valuable resources, which in turn enhance sustainable competitive performance. Resource acquisition partially mediates the relation between intellectual capital and sustainable competitive performance. Financial literacy is a significant predictor of resource acquisition, but it does not significantly moderate the relation between intellectual capital and sustainable competitive performance. Business experience significantly boosts the acquisition of resources and strengthens the path between intellectual capital and resource acquisition. SMEs should encourage their managers to acquire unique, rare, and immutable external resources in the turbulent markets.
\end{abstract}

Keywords: intangible skills; intellectual capital; financial literacy; business experience; resource acquisition; sustainable competitive performance

\section{Introduction}

In the current era of globalization, firms must have ample tangible and intangible resources to survive in the long run. Due to resource constraints and a lack of capabilities, many reputed firms have failed. For instance, a recent study indicates that more than $50 \%$ of newly established ventures shut down in the initial stage across the globe due to a lack of resources, a lack of competencies, and limited skills [1]. Resource base view (RBV) theory depicts that unique, rare, and immutable resources enable firms to gain sustainable competitive advantage [2]. A plethora of research has confirmed the significant influence of resources on firms' performance (e.g., [3-5]). However, acquiring resources such as land, equipment, machineries, information, finance, technology, and customers is a great challenge for business organizations. The first step is to determine what types of resources are 
crucial for venture success, and the next step is searching for the means to access resources, which has received comparatively little attention. Though a few studies (e.g., [6-8]) have investigated how firms' internal capabilities can facilitate access to external resources, the results are still fragmented. Notably, all the external resources do not come directly and automatically but require proper planning and competencies [9]. The question of how to acquire unique, rare, and immutable external resources is still under-discussed in the context of intangible management skills. More precisely, how SMEs (e.g., small or medium sized) can scan the external environment in a better way to acquire useful information that may facilitate resource acquisition is very important, but studies are lacking [10]. This research is an attempt to examine the influence of owners and top managers' intangible skills-intellectual capital (IC), financial literacy (FL), and business experience (BE) on resource acquisition-which in turn may influence sustainable competitive performance (SCP) in SMEs. These skills and capabilities (e.g., IC, financial literacy, and business experience) are essential for SMEs, as they do not have enough tangible resources (e.g., finance and technology) to acquire the external tangible and intangible resources to sustain their performance [4,9].

Resource acquisition is defined as the process by which a venture acquires resources from internal and external environments [11]. The primary goal of this research is to examine how firms' internal skills and capabilities (e.g., internal intangible resources) enable them to access external tangible and intangible resources. For instance, in emerging economies such as Pakistan, small firms often search external resources [1]. Prior studies have tried to discover firms' internal capabilities that can help in the access to external resources (e.g., $[8,12,13])$. However, top management capabilities (especially intangible skills) have been ignored in this context. The intangible skills such as IC, financial literacy, and business experience can help firms to acquire unique external resources that can in turn spur performance. For instance, the upper echelon theory focuses on the role of the top management capabilities and of skills in firms' success [14], but studies have rarely debated the intangible skills in resource acquisition in the upper echelon context. More importantly, how IC empowers firms to scan external resources and information that can boost competitiveness, value, sustainability, and performance is still unexplored [15].

We argue that top management intangible skills and capabilities are better than physical resources in accessing external resources. First, SMEs have a lack of resources to compete in the turbulent markets. Hence, they need a less expensive means to access valuable external resources. We argue that the top management skills-IC, financial literacy, and experience-being less expensive drivers, can benefit SMEs in acquiring scarce resources easily. Secondly, in emerging economies such as China and Pakistan, governments possess valuable resources [16]. In such regions, the management exertion and competencies (knowledge and relationship) can help to access external resources $[8,9]$. Thirdly, senior managers can find new opportunities in search of external resources. In other words, intellectual, experienced, and financially literate managers can discover new opportunities while searching for external resources. To summarize, the top management intangible skills can work as an alternative driver to physical resources through which SMEs access useful external resources.

This research answers the following questions: Does IC influence SCP? Does resource acquisition mediate the relation between IC and SCP? Do financial literacy and experience of top management moderate the link between IC and resource acquisition? More importantly, how can internal intangible skills/resources/capabilities help in acquiring external intangible and tangible resources? In turn, this research enables firms to emphasize intangible resources rather than a massive investment in physical means. This research contributes to the RBV theory where vehemence is given to tangible and intangible resources regarding high performance [2]. Though, in the RBV theory, it is clearly expressed that unique, rare, and immutable resources upsurge firms' sustainable competitive advantage [2], but how external resources (tangible and tangible) can be acquired in an inexpensive way is still underemphasized. In other words, this study aims to discover less expensive itineraries of access to external resources, which in turn can lead to SCP. Similarly, this research also adds to the upper echelon theory that describes the role of top management background (education, experience and 
skills, etc.) and the psychological characteristics in firms' outcome [14]. Additionally, this research gives a clear picture of how IC endues firms to rake the environmental pressure and acquire unique resources that are beneficial for SCP [15].

This article is organized as follows. In the introduction section, we discuss the problem statement, research gap, research questions, research objectives, and the overall contribution. The second section is about the theories and review of the previous studies. The third section is related to methodology, and we discuss data analysis results and conclude in the fourth section.

\section{Hypotheses Development}

\section{Intellectual Capital and Sustainable Competitive Performance}

In turbulent markets, firms race to gain high profit and to survive in the long run. To achieve these objectives (e.g., high profit and a long-term survival), firms invest a massive amount of money in tangible and intangible resources [17]. However, recent studies have pointed out that investment in intangible resources-especially in IC-spurs SCP in emerging firms $[4,18]$. IC encompasses structural capital, human capital, and relational capital that might give a high return to business firms [19]. The dimensions mentioned earlier of IC are not only crucial for industry competitiveness but also play a prominent role in sustainability, economic growth, and economic performance [20]. Moreover, $\mathrm{Xu}$ and Wang [21] confirmed that all the dimensions of IC-structural capital, human capital, and relational capital-significantly and positively enhance sustainability, financial performance, and economic growth in the business sector. Especially SMEs, due to a lack of resources and capabilities, can acquire a great advantage of IC, as it is considered less risky and a convenient resource [18]. Top managers are required to intensify initiative to encourage the promotion of IC (human capital, structural capital and relational capital) inside organizations to acquire competitive advantage [22]. In the current era of globalization, IC has been considered as an effective strategy of business firms that leads to financial performance [23] as well as significantly enhances non-financial performance [24], innovative performance [25] and competitive advantage [18]. In other words, a recent study has confirmed that IC significantly improves SCP [26]. Therefore, we hypothesize the following:

Hypothesis H1. Intellectual capital significantly positively influences sustainable competitive performance.

\section{Intellectual Capital and Resource Acquisition}

Firms face various challenges in an uncertain market. In such an atmosphere, entrepreneurial networking helps them to acquire sustainable resources [27]. Strong entrepreneurial abilities and network ties empower firms in emerging economies to gain useful resources (e.g., financial and technological) that are akin to high profitability [28]. Intellectual capabilities in top managers enable them to do proper strategic planning and effectively use the resources to gain high performance [29]. Firms are encouraged to invest in IC, as it reconfigures the internal process (reducing various costs) to search for external resources to gain efficiency [30]. Hence, for accessing useful resources, firms improve their social capital and external relationship with governments and other bodies [31]. The role of IC is not confined to a specific industry, but various industries benefit from IC in terms of scanning external environments and exploiting opportunities. For instance, $\mathrm{Li}$ and Liu [32] investigated whether IC is useful in the service industry (e.g., the hospital sector) in challenging environments in that information that is essential for a high degree of competitiveness can be critically analyzed. Otcenášková and Bureš [33] claimed that business organizations in the current turbulent environment use IC to acquire adequate knowledge and resources to respond to external pressure. SMEs especially reconfigure their intellectual abilities to access financial resources that are essential for their growth and long-term survival [34]. IC—-being an intangible resource-facilitates firms in acquiring useful information about the market trends, upward and downward, environmental issues, and competition pressure [35]. Promoting skills such as human capital, relational capital, and structural capital influence 
the embeddedness of resource integration among firms [36]. For instance, Lee et al. [37] argue that social capital helps firms to acquire both tangible and intangible resources that may not be gained through other sources. Therefore, we hypothesize the following:

Hypothesis H2. Intellectual capital significantly positively influences resource acquisition.

\section{Resource Acquisition and SCP}

Despite the burgeoning discussion on the RBV theory, how a firm transforms its resources into superior performance remains in a black box [11]. RBV theory demonstrates the role of both tangible and intangible resources in sustainable competitive advantage [2]. In this perspective, a few studies (e.g., [38,39]) have recommended physical factors in SCP, while others (e.g., [4,40]) give more weight to intangible resources, but the results are fragmented. In fact, firms should not emphasize on the tangible or intangible, but instead consider the acquisition of both types of resources. Notably, new ventures need enough resources in the initial stage to avoid failure. As described by RBV theory, the performance of newly established ventures is significantly and directly related to resource acquisition as the availability of adequate resources is crucial for superior performance [41]. In a similar context, Shane [42] demonstrates that obtaining adequate resources not only helps a venture to pursue its recognized opportunities but also leads to its aptitude, ability, and skills to generate high profits, grow, respond to the competition, and survive in the long run. Moreover, it is determined that sufficient resources are necessary to perform the operational activities smoothly and gain high profit [8]. A firm can pursue different methods for resource acquisition, such as resource attraction, resource purchase, and internal resource development. These resources, in turn, generate different outcomes, which might depend on the resources and relationships that a firm holds with partners or that are wholly owned by the firm. However, a cost is aligned with whatever method of resource acquisition a firm uses. To summarize, sustainable resources acquisition can lead to the survival of business ventures in the long run [27]. Therefore, we hypothesize the following:

Hypothesis H3. Resource acquisition significantly positively influences sustainable competitive performance.

\section{The Mediating Role of RA}

IC pertains to social capital-“"the networks of relationships among people who live and work in a particular society, enabling that society to function effectively" that in turn can affect firms' performance, but a significant mediating role is played by resource acquisition [8]. Resources are tangible (financial, technological, etc.) and intangible (corporate social responsibility, financial capability, goodwill, etc.), and are necessary for sustainable competitive performance [4]. The intangible resources such as knowledge management (which can be acquired through IC) can affect firms' performance [43]. However, again, that either tangible or intangible resources are useful for SCP is still unclear. However, top management must ensure the availability of both tangible (finance, machinery, technology, land, etc.) and intangible (knowledge, information, skills, competencies, etc.) resources, as both are considered significant drivers of high profitability [39]. One way to acquire adequate resources is IC that can make it easy for firms to seize scarce resources. For instance, IC strengthens the internal structure of organizations where resources are utilized innovatively to gain competitive advantage [44]. Managerial competencies (skills, knowledge, etc.) indirectly contribute to firms' performance via creating sustainable competitive advantage through unique resources [45]. From the upper echelon theory perspective, the top management capabilities and skills are significant drivers leading to firms' outputs [14]. However, senior managers may not spur the performance of the firms directly but can first acquire enough resources that are necessary for smooth operation, which in turn can enhance competitive performance.

Especially for the growth and sustainable performance of SMEs, adequate resources are necessary. SMEs use their internal capabilities and social capital to acquire the valuable resources, which in turn 
can provide a competitive advantage and superior performance [46]. IC does not directly enhance firms' performance, but firms' internal management practices and resources mediate the relation [47]. Moreover, whether IC creates a competitive advantage by utilizing resources efficiently and effectively has also been invesitigated [18]. We argue that intellectual managers can facilitate firms in accessing rare, unique, and immutable resources that are necessary for high performance and growth. Therefore, we hypothesize the following:

Hypothesis H4. The relation between intellectual capital and sustainable competitive performance is mediated by resource acquisition.

\section{Financial Literacy, Business Experience, and Resource Acquisition}

Financial literacy is the ability to use knowledge and skills to accomplish firms' financial resources effectively, which in turn can enhance financial performance [48]. However, financial literacy is not only aligned with the management of financial resources, but financial literate managers can also reduce different types of cost, exploit new opportunities, and help to access useful resources (e.g., [49]). Financial skills enable managers to identify opportunities, solve problems, attain valuable resources, and manage the internal business processes adequately. Moreover, financial skills and education avoid SMEs from failure [50]. Financial education reconfigures financial and non-financial resources that may provide high economic growth and financial stability [51]. Financially related skills influence the earning management of firms [52]. Financially literate managers are capable of acquiring external finance that is necessary for the smooth running of operational activities among SMEs [53]. Regrettably, many SMEs due to a lack of financial management skills are unable to access eminent resources [54]. Additionally, limited financial skills can negatively influence the innovative performance and growth of SMEs [55] as scarcity of financial management skills may hamper managers from acquiring valuable, unique, and immutable resources.

Dittmar and Duchin [56] pointed out that experienced managers use resources (e.g., finance) efficiently. They are less debt-oriented and save more cash for their firms. Moreover, it is argued that experienced managers can better forecast future earnings and can manage future cash flow effectively, which in turn yields higher profitability [57]. A CEO's experience significantly influences the firm's financial resources, debt, equity, and capital structures [58]. Psychological characteristics and top management experience matter in firm's policies and dynamic capabilities [59]. Experienced managers can divulge external sources as new markets, new opportunities, and new ways of gaining performance [60]. Prior experience endows managers to tackle the environmental pressure and resources in a positive way that can yield better investment opportunities [61]. Financial experts and experienced CEOs are not only conscious of financial policies but also care for firms' financial and non-financial resources. They try to use resources (financial and non-financial) in a way that spurs their firms' performance [62]. To summarize, we argue that financial experienced owners/managers will be able to acquire useful and scarce resources easily that are very beneficial for high profitability. Therefore, we hypothesize the following:

Hypothesis H5. Financial literacy significantly positively influences sustainable competitive performance.

Hypothesis H6. Business experience significantly positively influences sustainable competitive performance.

\section{The Moderating Role of Financial Literacy}

Numerous studies have concluded that IC directly contributes to SCP (e.g., [63,64]), while others claim that superior performance cannot be directly gained through IC but that a firm's internal capabilities and resources such as competitive advantage [18], knowledge management [43], innovation $[65,66]$, etc. affect the relation. However, it is still unclear as to whether IC directly influences external resource acquisition (tangible and intangible) or needs the support of top management 
experience and financial literacy. Favoring studies that show an indirect influence of IC on SCP, we posit that financial literacy and business experience can facilitate IC in accessing external resources that are important for SCP.

Financial literacy is categorized as internal financial literacy and external financial literacy. Internal financial literacy assists top managers to optimize the use of scarce resources by an effective and efficient management system. On the other hand, external financial literacy describes the necessary skills and knowledge of top management to set up an external network and to use communication and cognitive skills to achieve satisfactory outputs and desirable objectives [67]. In general, financial literacy alleviates managers to use additional knowledge (e.g., financial) for acquiring useful resources, material, and means that can boost and enlighten the production processes and operational activities, which in turn can improve profitability $[53,68]$. Financial literacy encompasses the knowledge and understanding of top managers toward different financial practices. It is argued that financial knowledge increases abilities of financial accountants, who in turn outperform others [19]. Financial skills and literacy endue managers with an ability to make a good strategic decision and timely interference to deal with an uncertain situation and with a sophisticated financial decision [69]. Financial literacy can facilitate better usage of governing skills and practices to use financial resources effectively. In contrast, governing bodies lacking literacy face difficulty in using financial resources [70] efficiently. Firms need to reduce different types of costs related to operation, supplies, and sales to improve their competitive performance. To achieve this goal, managers must be financially literate to use the resources efficiently to gain a sustainable competitive advantage [49]. Educated CEOs can affect firms' resources and operational activities in a way that can yield a high value and efficiency in the long run [71]. Financial experts and CEOs are more financially sophisticated. They can use different discounting strategies and adequate cash flow practices in investment decisions. These practices, in turn, facilitate reductions in costs, which significantly improve competitive performance [62]. Therefore, we hypothesize the following:

Hypothesis H7. Financial literacy moderates the relation between intellectual capital and resource acquisition such that the link will be stronger when there is high financial literacy.

\section{The Moderating Role of Top Managers' Business Experience}

As mentioned, firms need enough resources (tangible and intangible) to survive in the long run. For this, a firm needs very competent, intellectual, and experienced managers who have, or can build a relationship with, external bodies and can learn about market trends [13]. CEOs who have worked in businesses for a long time are deemed experienced CEOs. The long-term experience enables them to better formulate the financial policies of their firms and reduce costs to gain superior performance [62]. Moreover, it is believed that experience in business and industries enables top managers and founders to acquire both financial and non-financial external resources that are essential for the success of new ventures [72]. It is doubtless that top management social capital effectively stimulates the R\&D of a firm. However, in addition to the social capital, business experience helps them to access useful resources and to establish a corporate R\&D alliance [73]. Intellectual abilities of top managers can assist them in operational processes. However, prior experience reconfigures and shapes their capabilities and skills in that they inquire information about environmental uncertainty, pressure, and market trends that can facilitate the strategic decision-making process [61]. Senior managers' interpersonal skills assist them in making good strategic decisions. However, functional experience helps them to focus on useful external resources that can supercharge the operational and production activities [74]. Additionally, that firms' competitiveness and economic performance can be enhanced through top management intellectual and social abilities is scrutinized. However, the experience is considered an excellent factor in strengthening the relation efficiently [75]. We argue that IC can facilitate firms in accessing resources, but business experience makes this easy for a firm to acquire useful resources (see Figure 1). Therefore, we hypothesize the following: 
Hypothesis H8. Business experience moderates the relation between intellectual capital and resource acquisition such that the link will be stronger when managers are more experienced.

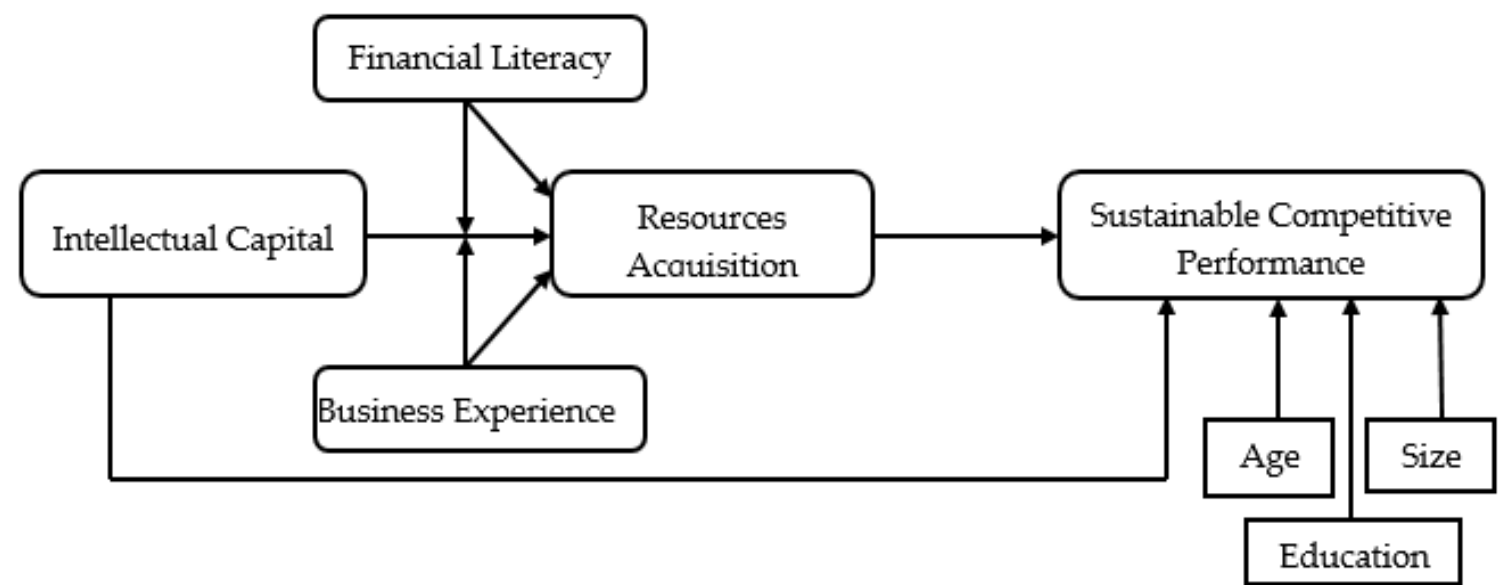

Figure 1. Research model.

\section{Methodology}

\section{Design, Population, and Sample}

We collected cross-sectional data (e.g., within two months) through a structured questionnaire from top managers of Pakistani SMEs. We used the English version of the questionnaire, as English is spoken as a second language in Pakistan. SMEs are reluctant to provide information to the general public, so we disclosed in the questionnaire that the data collected will be used only for research purposes and will not be shared publicly. We selected three large cities in Pakistan, Rawalpindi, Islamabad, and Peshawar, because the head offices of many firms are located in these cities, where owners and managers are performing their duties [76]. The lists of the registered firms were obtained on request from the Islamabad Chamber of Commerce and Industry (registered firms 3753), the Rawalpindi Chamber of Commerce and Industry (5817), and the Sarhad Chamber of Commerce and Industry (2072). We randomly selected 482 firms as a sample (e.g., applied-probability-based sampling formula with a 5\% margin of error and a confidence level 95\%) out of total 11,642 firms. We focused on owners and managers, as they are well aware of their business information and strategic planning. After the distribution of 900 questionnaires (300 in each city), we received 384 usable questionnaires with a response rate of $42.67 \%$. The firms who participated in the study are shown in Table 1.

Table 1. The demographic detail of the firms.

\begin{tabular}{rcc}
\hline \multicolumn{1}{c}{ Description } & Frequency & Percentage \\
\hline Firms by Industry & & \\
1. Manufacturing & 137 & 35.7 \\
2. Trading & 151 & 39.3 \\
3. Services & 96 & 25.0 \\
\hline Size of the firms & & \\
1. 20-50 employees & 90 & 23.4 \\
2. 51-100 employees & 76 & 19.8 \\
3. 101-150 employees & 69 & 18.0 \\
4. 151-200 employees & 78 & 20.3 \\
5. 201 to 250 employees & 71 & 18.5 \\
\hline
\end{tabular}


Table 1. Cont.

\begin{tabular}{lcc}
\hline \multicolumn{1}{c}{ Description } & Frequency & Percentage \\
\hline Age of the firms & & \\
1. 10 years and less & 141 & 36.7 \\
2. 11-20 years & 137 & 35.7 \\
3. 21 and above years & 106 & 27.6 \\
\hline Owners/Managers Education & & \\
1. Intermediate and less & 63 & 16.4 \\
2. Bachelor & 130 & 33.9 \\
3. Master & 131 & 34.1 \\
4. MS / MPhil & 53 & 13.8 \\
5. PhD & 7 & 1.8 \\
\hline Total & 384 & 100 \\
\hline
\end{tabular}

\section{Variables and Measures}

Intellectual capital: IC encompasses the intangible abilities of a firm. Prior studies have measured IC with various dimensions such as human capital, organization capital, relational capital, customer capital, etc. (e.g., [4,18]). We relied on the measurement used in the context of SMEs. Six items were used by Khan, Yang, and Waheed [4]. We asked participates to respond to the following: "Our firm has a clear view of knowledge, information, strategy, etc." See Table 3 for detail. Five Likert scales were given representing strongly disagree, 1 , to strongly agree, 5 .

Resource acquisition: Firms need tangible and intangible resources to survive in the long run. To gain more helpful insights, we aimed to check how a firm can acquire external resources (tangible and intangible) through IC. Thus, we used six items to measure resource acquisition that were merged and adopted from prior studies (e.g., [12,37]). Five Likert scales were given representing strongly disagree, 1 , to strongly agree, 5 .

Business experience: This demonstrates the working experience of owners and top managers in terms of purchase, sale, operation, etc. To measure owners and senior managers' experience, we asked them to indicate their experience in terms of import/export, decision making, problem-solving, etc. The options were given as very low, 1, to very high, 5 .

Financial literacy: Financial literacy indicates how a manager or owner knows the financial terms, financial management, financial practices, etc. To measure financial literacy, studies have used questions related to interest rate and inflation, etc. However, in the business context and especially in SMEs, studies have preferred measures related to financial management, working capital, and financial reporting (e.g., [77]). Thus, to measure financial literacy, we relied on 13 items used by Yang, Ishtiaq, and Anwar [49]. Five Likert scales were given representing strongly disagree, 1, to strongly agree, 5.

Sustainable competitive performance: We used eight items to measure SCP that were adopted from Degong et al. [3]. Owners and managers were asked how their firms have performed on return on equity, return on investment, return on assets, etc. in the last three years as compared to their major competitors. Five Likert scales were given representing extremely declined, 1, to extremely improved, 5 .

\section{Control Variables}

Recommended by prior studies, we included four often-used variables as control variables: firm age, size, nature of the industry, and the educational background of owner and managers. We used group difference analysis for the nature of the industry (being a categorical variable). We found no significant difference between any groups. Hence, due to less importance of the variable (the nature of industry), we dropped it from the control variables. The results indicated that only the age of firms has a significant influence on SCP, while the size of the firms and the educational background are not significantly related to SCP. 


\section{Results}

We conducted descriptive statistics in SPSS to examine the mean, standard deviation (S.D.), and normality of the sample (see Table 2). Our data are normal as the skewness and kurtosis values are found in the recommended range \pm 2 [9].

Table 2. Descriptive statistics.

\begin{tabular}{ccccccc}
\hline Factors & Minimum & Maximum & Mean & Std. Deviation & Skewness & Kurtosis \\
\hline Intellectual Capital & 1.72 & 4.14 & 3.0640 & 0.34845 & -0.450 & 1.377 \\
Financial Literacy & 2.25 & 4.65 & 3.5045 & 0.33563 & 0.073 & 2.843 \\
Business Experience & 2.02 & 4.49 & 3.3116 & 0.36348 & -0.041 & 0.667 \\
Resource Acquisition & 1.90 & 4.33 & 3.2332 & 0.40908 & -0.232 & 0.842 \\
SCP & 2.26 & 4.98 & 3.7958 & 0.42390 & -0.556 & 2.108 \\
\hline
\end{tabular}

\section{Confirmatory Factor Analysis}

Standardized factor loading, validity, and reliability of the data were checked in the measurement model (see Figure 2). All items have an acceptable standardized factor loading (above 0.70) and were significantly aligned $(p<0.001)$ with the respective factor (see Table 3$)$. The model fits such as $\chi^{2} / \mathrm{df}=2.437, \mathrm{GFI}=0.84, \mathrm{AGFI}=0.81, \mathrm{TLI}=0.91, \mathrm{NFI}=0.88, \mathrm{RM}=0.014$, and $\mathrm{RMSEA}=0.061$ values are found in the acceptable range (e.g., $[78,79])$.

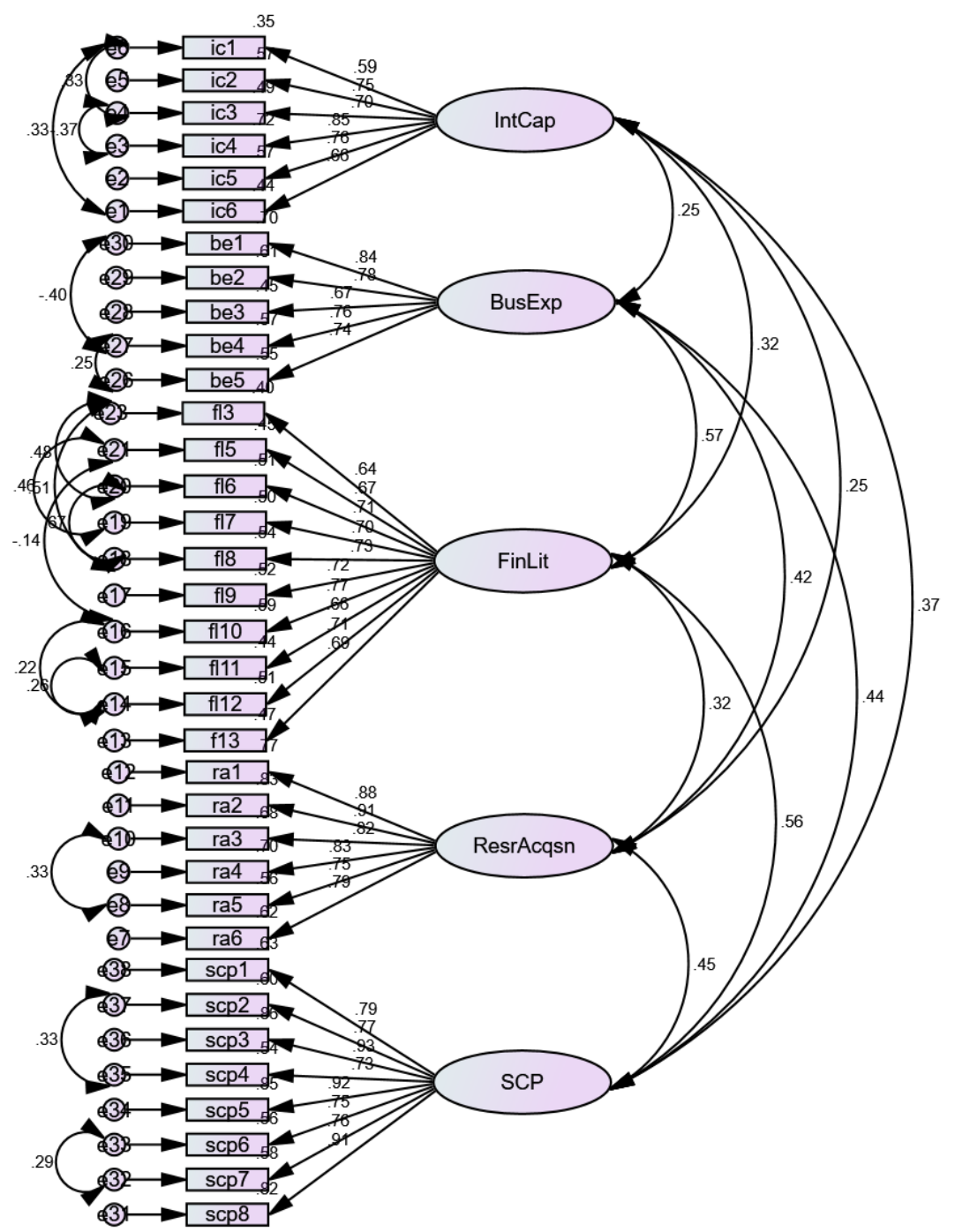

Figure 2. Measurement model. 
Table 3. Standardized factor loading.

\begin{tabular}{|c|c|c|}
\hline Sr. No. & Variables and Items & Estimate \\
\hline \multicolumn{3}{|c|}{ Intellectual Capital } \\
\hline ic6 & A clear strategy for developing knowledge & 0.661 \\
\hline ic5 & Explicit recognition of knowledge as a key factor of strategic planning & 0.756 \\
\hline ic 4 & Benchmarking strategy knowledge against that of competitors & 0.846 \\
\hline ic3 & Proper evaluation of knowledge and competences & 0.699 \\
\hline ic2 & knowledge and competencies that are more relevant for objectives & 0.753 \\
\hline ic1 & Core knowledge & 0.594 \\
\hline \multicolumn{3}{|c|}{ Financial Literacy } \\
\hline $\mathrm{f} 13$ & The manager of this business has basic accounting knowledge & 0.688 \\
\hline $\mathrm{fl} 12$ & We have skills of minimizing losses by minimizing bad debts & 0.713 \\
\hline fl11 & We have required skills to ascertain the financial trends of the firm & 0.665 \\
\hline $\mathrm{fl} 10$ & The firm is able to correctly calculate interest rates on my loan payments & 0.765 \\
\hline $\mathrm{fl} 9$ & We are aware of the costs and benefits of accessing credit & 0.724 \\
\hline $\mathrm{fl} 8$ & We are aware of the operations of lending firms relating to our financial needs & 0.732 \\
\hline $\mathrm{fl} 7$ & The entrepreneur can prepare basic books of accounts & 0.705 \\
\hline $\mathrm{fl} 6$ & My enterprise operates a savings account & 0.711 \\
\hline $\mathrm{fl} 5$ & The management of this business can compute the cost of its loan funds & 0.668 \\
\hline $\mathrm{fl} 4$ & My enterprise has bought formal insurance for our businesses & dropped \\
\hline $\mathrm{fl} 3$ & We receive training on proper bookkeeping skills & 0.635 \\
\hline $\mathrm{fl} 2$ & My enterprise makes monthly income returns to the lender & dropped \\
\hline fl1 & We have the ability to analyze our financial performance periodically & dropped \\
\hline \multicolumn{3}{|c|}{$\begin{array}{l}\text { Business Experience } \\
\end{array}$} \\
\hline be5 & Domestic business experience & 0.741 \\
\hline be4 & Exports and imports experience & 0.756 \\
\hline be3 & Problem-solving experience & 0.671 \\
\hline be2 & Decision-making experience & 0.781 \\
\hline be1 & Resource management and utilization experience & 0.839 \\
\hline \multicolumn{3}{|c|}{ Resource Acquisition } \\
\hline ra6 & Financial support & 0.790 \\
\hline ra5 & Business strategy advise & 0.746 \\
\hline ra4 & Social capital & 0.835 \\
\hline ra3 & Physical resources (e.g., technologies, equipment, etc.) & 0.823 \\
\hline ra2 & Corporate social responsibility & 0.912 \\
\hline ra1 & Industry information & 0.878 \\
\hline \multicolumn{3}{|c|}{ Sustainable Competitive Performance } \\
\hline scp8 & Return on investment (ROI) & 0.907 \\
\hline scp7 & Profits as a percentage of sales & 0.759 \\
\hline scp6 & Decreasing product or service delivery cycle time & 0.745 \\
\hline scp5 & Rapid response to market demand & 0.920 \\
\hline scp4 & Rapid confirmation of customer orders & 0.732 \\
\hline scp3 & Increasing customer satisfaction & 0.929 \\
\hline scp2 & Increasing profit growth rates and growing market shares & 0.774 \\
\hline scp1 & In reducing operating costs & 0.793 \\
\hline
\end{tabular}

Convergent validity, discriminant validity, and composite reliability (CR) are shown in Table 4 . Convergent validity was executed and confirmed that each factor has acceptable convergent validity (above 0.50 ). In other words, the value higher than 0.50 shows the sufficient average variance extracted (AVE) by the items $[78,79]$. Discriminant validity (the square root of AVE) also provided an acceptable value (above 0.70 ) for all factors [78]. Additionally, CR was assessed to examine the internal consistency of the factors. CR also showed an acceptable value (greater than 0.70 ) as per the recommendation of [80]. Cronbach's alpha of all the factors is higher than the cut-off threshold (0.70), which indicates satisfactory reliability [78]. 
Table 4. Correlation.

\begin{tabular}{|c|c|c|c|c|c|c|c|c|c|c|c|}
\hline Factors & Alpha & AVE & CR & 1 & 2 & 3 & 4 & 5 & 6 & 7 & 8 \\
\hline 1. Age & - & - & - & - & & & & & & & \\
\hline 2. Size & - & - & - & 0.063 & - & & & & & & \\
\hline 3. education & - & - & - & -0.039 & -0.018 & - & & & & & \\
\hline 5. Financial Literacy & 0.92 & 0.50 & 0.91 & $0.294^{* *}$ & 0.025 & 0.011 & $0.355^{* *}$ & 0.70 & & & \\
\hline 6. Business Experience & 0.87 & 0.58 & 0.87 & $0.227^{* *}$ & 0.051 & -0.026 & $0.277^{* *}$ & $0.622^{* *}$ & 0.76 & & \\
\hline 7. Resource Acquisition & 0.93 & 0.69 & 0.93 & $0.214^{* *}$ & 0.060 & 0.010 & $0.268^{* *}$ & $0.367^{* *}$ & $0.450^{* *}$ & 0.83 & \\
\hline
\end{tabular}

\section{Correlation Coefficients}

Table 4 shows correlation coefficients of the sample executed in SPSS. We found a significant positive correlation between IC and resource acquisition $(\mathrm{r}=0.268, p<0.01)$, a significant positive correlation between IC and SCP $(r=0.399, p<0.01)$, a significant positive correlation between financial literacy and resource acquisition $(r=0.367, p<0.01)$, a significant positive correlation between financial literacy and SCP $(\mathrm{r}=0.599, p<0.01)$, a significant positive correlation between business experience and resource acquisition $(\mathrm{r}=0.450, p<0.01)$, a significant positive correlation between business experience and SCP $(\mathrm{r}=0.470, p<0.01)$, and finally a significant positive correlation between resource acquisition and SCP $(r=0.477, p<0.01)$.

\section{Common Method Bias}

This research is based on cross-sectional data (e.g., data collected through a single source, from the same respondent on the same time), which may create a common method bias [81]. To check the issue of prejudice, we executed Harman's one-factor test in SPSS using principal component analysis. We encountered five factors that have an eigenvalue greater than 1 . The first factor explained only $34.36 \%$ variance that is lower than $50 \%$. Thus, we confirmed the non-existence of the common method problem in this research.

\section{Structural Model}

Hypotheses of the research were tested in the structural model. To articulate the results in a better way, we conducted separate models for mediator and moderators.

\subsection{Structural Model 1}

The first structural model (see Figure 3) was performed to check the mediating role of resource acquisition between IC and SCP. We confirmed the model fits such as $\chi 2 / \mathrm{df}=3.476, \mathrm{GFI}=0.97$, AGFI $=0.94, \mathrm{TLI}=0.85, \mathrm{NFI}=0.88, \mathrm{RM}=0.030$, and RMSEA $=0.08$, as recommended by Hair et al. [78] and $\mathrm{Hu}$ and Bentler [79].

The results show (see Table 5) that IC has a significant influence on SCP $(\beta=0.201, p<0.05)$ that supported H1. IC also has a significant influence on resource acquisition $(\beta=0.246, p<0.05)$ and thus supported H2. Resource acquisition has a significant impact on SCP $(\beta=0.333, p<0.05)$, which also supported H3. Moreover, the indirect impact of IC on SCP is significant $(\beta=0.081, p<0.05)$, while the direct impact of IC on SCP remained significant (e.g., $\beta=0.26, p<0.05$ ), which partially supported H4.

In the control variables, the age of the firms and education have a significant influence on SCP, while the size of firms does not. The square shows that the 39\% variance in SCP can be explained by IC when resource acquisition plays a mediating role. 


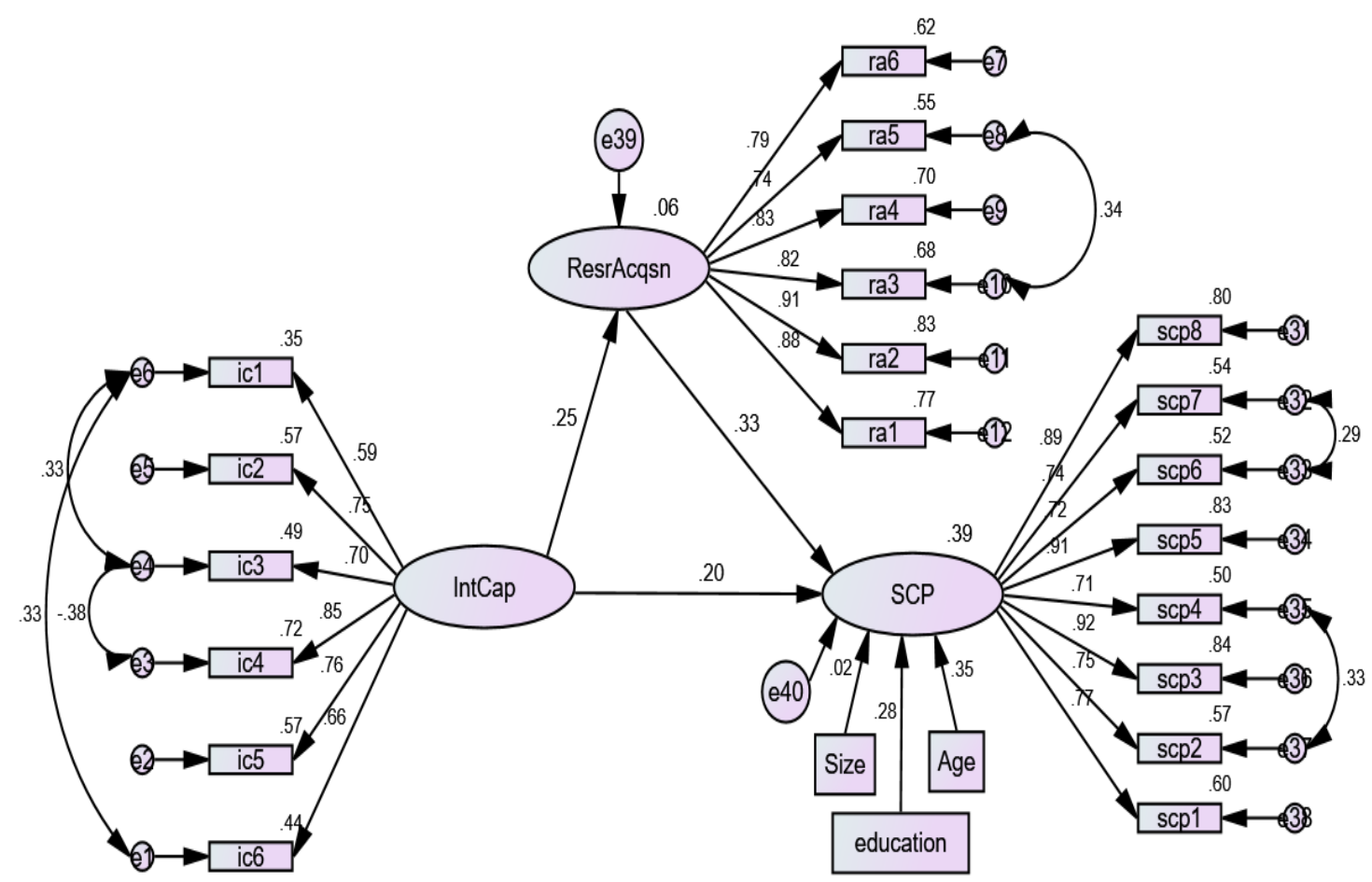

Figure 3. Structural Model 1.

Table 5. Hypotheses testing (mediation).

\begin{tabular}{lcccccc}
\hline \multicolumn{1}{c}{ Hypotheses } & $\begin{array}{c}\text { Direct } \\
\text { Effect }\end{array}$ & $\boldsymbol{p}$ & $\begin{array}{c}\text { Indirect } \\
\text { Effect }\end{array}$ & $\boldsymbol{p}$ & $\begin{array}{c}\text { Total } \\
\text { Effect }\end{array}$ & $p$ \\
\hline SCP <-int. capital (through resource acquisition) & 0.201 & 0.001 & 0.082 & 0.000 & 0.246 & 0.001 \\
Resource acquisition <-Intellectual capital & 0.246 & 0.001 & - & - & 0.246 & 0.001 \\
SCP <-Resource acquisition & 0.333 & 0.001 & - & - & 0.333 & 0.001 \\
SCP <-Age & 0.353 & 0.001 & - & - & 0.353 & 0.001 \\
SCP <-Size & 0.025 & 0.636 & - & - & 0.025 & 0.636 \\
SCP <-Education & 0.278 & 0.001 & - & - & 0.278 & 0.001 \\
\hline
\end{tabular}

\subsection{Structural Model 2}

The second structural model (see Figure 4) was performed for testing the moderating role of financial literacy and business experience between IC and resource acquisition. The results show (see Table 6) that financial literacy has a significant influence on resource acquisition $(\beta=0.39, p<0.05)$ supporting H5. However, financial literacy as a moderator (e.g., IC x FL) does not significantly moderate the relation between IC and resource acquisition $(\beta=0.015, p>0.05)$, which does not support H7. The size of firms as a control variable has a significant impact, while the age of firms has no significant influence on resource acquisition. $\mathrm{R}$ square indicates that the $16 \%$ variance is explained by resource acquisition when financial literacy has interacted with IC. 


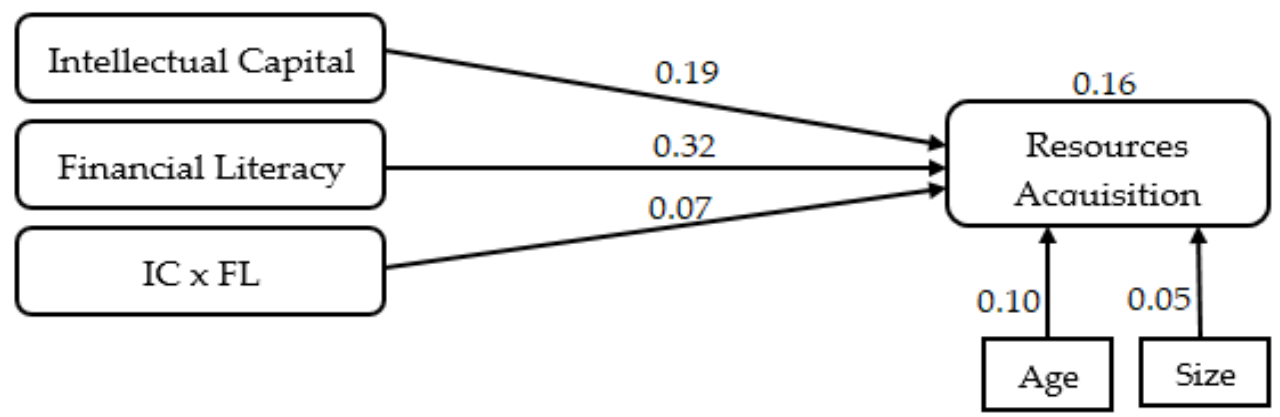

Figure 4. Structural Model 2. (Note: The values $0.19,0.32$, and 0.07 are standardized weight. In Table 6, the values are unstandardized). $\mathrm{x}=$ shows interaction/multiplication of IC and financial literacy.

Table 6. Hypotheses testing (moderating role of financial literacy).

\begin{tabular}{lcccccc}
\hline & Hypotheses & & Estimate & S.E. & CR & $p$ \\
\hline Resource acquisition & $<-$ & Intellectual capital & 0.226 & 0.055 & 4.134 & 0.000 \\
Resource acquisition & $<-$ & Financial Literacy & 0.390 & 0.057 & 6.863 & 0.000 \\
Resource acquisition & $<-$ & IC x FL & 0.015 & 0.010 & 1.424 & 0.155 \\
Resource acquisition & $<-$ & Age & 0.052 & 0.024 & 2.165 & 0.030 \\
Resource acquisition & $<-$ & Size & 0.014 & 0.013 & 1.038 & 0.299 \\
\hline
\end{tabular}

Note: IC = intellectual capital, FL = Financial literacy.

\subsection{Structural Model 3}

This structural model (see Figure 5) was executed to assess the moderating role of business experience between IC and resource acquisition. The results show (see Table 7) that business experience has a significant influence on resource acquisition $(\beta=0.251, p<0.05)$, which supports H6. Business experience as a moderator (IC $\times \mathrm{BE}$ ) also significantly moderates the relation between IC and resource acquisition $(\beta=0.035, p<0.05)$, which supports H8. The age and size of firms as control variables are not significantly associated with resource acquisition. $\mathrm{R}$ square shows that the $13 \%$ variance in resource acquisition is explained by the moderating role played by the business experience interacting with IC.

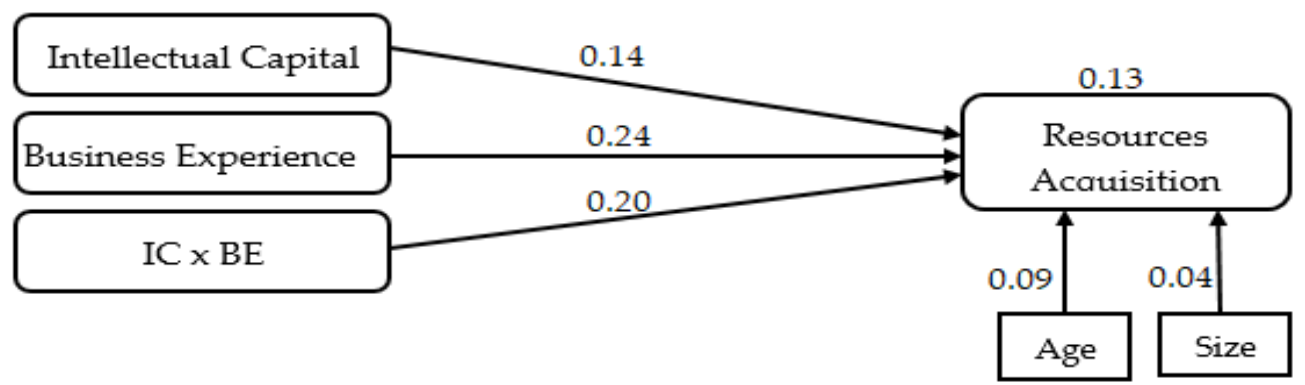

Figure 5. Structural Model 3.

Table 7. Hypotheses testing (moderating role business experience).

\begin{tabular}{lclcccc}
\hline & Hypothesis & & Estimate & S.E. & CR & $p$ \\
\hline Resource acquisition & $<-$ & Size & 0.010 & 0.013 & 0.782 & 0.434 \\
Resource acquisition & $<-$ & Age & 0.043 & 0.023 & 1.863 & 0.062 \\
Resource acquisition & $<-$ & Intellectual capital & 0.149 & 0.052 & 2.852 & 0.004 \\
Resource acquisition & $<-$ & Business experience & 0.251 & 0.050 & 5.003 & 0.000 \\
Resource acquisition & $<-$ & IC x BE & 0.035 & 0.008 & 4.240 & 0.000 \\
\hline
\end{tabular}

Note: $\mathrm{IC}=$ intellectual capital, $\mathrm{BE}=$ Business experience 


\section{Discussion}

Our research found that IC significantly contributes to resource acquisition and SCP and thus supports H1 and H2. This is in line with prior studies where Khan, Yang, and Waheed [4] argued that intangible resources such as IC could help firms to utilize their resources efficiently to gain SCP. Moreover, Kamukama and Sulait [22] claimed that IC (such as human capital, structural capital, and relational capital) helps firms in establishing a sustainable competitive position in turbulent markets. In a similar context, our research favors Lee et al. [37], who investigated whether IC helps firms to gain tangible and intangible means. These resources, in turn, can lead to SCP (e.g., [8,42]), thus supporting $\mathrm{H} 3$. In addition to this, we conclude a partial mediating role of resource acquisition between IC and SCP, which partially supports $\mathrm{H} 4$.

The direct influence of financial literacy on resource acquisition shows significant value, which supports H5. However, financial literacy does not significantly moderate the relation between IC and resource acquisition, which does not support H7. Unlike Mestry [70] and Yang, Ishtiaq, and Anwar [49], who demonstrated a significant role of financial literacy in managing and utilizing resources, we found that financial literacy does not significantly help top managers to acquire rare, unique, and immutable resources. Senior managers of Pakistani firms likely have low financial literacy, which may hinder their venture's growth. For instance, in a survey conducted by Klapper et al. [82], conducted to examine financial literacy across the globe, Pakistan shows the lowest rate of financial literacy. However, we found that business experience enables top management to acquire scarce resources and strengthens the relation between IC and resource acquisition, thus supporting $\mathrm{H} 6$ and H8. The same results are discussed by Murray, Hallen, and Kotha [13]: business experience helps management to secure resources effectively. Moreover, it is argued that experience in business and industries enables top managers and founders to acquire both financial and non-financial external resources that are essential for the survival of new ventures [72]. We confirmed that experience directly, and as a moderator, helps SMEs in resource acquisition. In general, IC directly influences resource acquisition and requires the support of top management experience. However, our results indicate that IC does not significantly need the support of financial literacy (as a moderator) to acquire external resources.

\section{Conclusions}

In the current era of globalization, staying competitive in the long run has become a challenge for business and non-business organizations. SMEs especially, due to the limited resources and support, are unable to respond to the external pressure and competition. Hence, owners and managers of SMEs often hunt for less expensive and less costly resources that can facilitate sustainable performance. As stated earlier, SMEs are probably unable to invest in physical means due to their limited budgets. Hence, intangible resources may be the best option on this occasion. However, little is known about the role of intangible skills in acquiring external resources (tangible and intangible) that are essential for competitiveness. This research aims to learn about top management's intangible skills and resources that play a significant role in accessing external tangible and intangible resources, which in turn can boost firms' SCP. Based on the RBV and upper echelon theory, this study examines the role of IC in SCP with a mediating role of resource acquisition. We also tested the moderating role of financial literacy and business experience of top management between IC and resource acquisition. To test the model, we collected data through a structured questionnaire (e.g., hard copy) from 384 owners/managers of Pakistani SMEs. The analyses of this research were done through structural equation modeling in AMOS. The results indicate that IC significantly helps in resource acquisition and contributes to SCP. Resource acquisition significant improves SCP and partially mediates the relations between IC and SCP. Financial literacy is a significant predictor of resource acquisition, but, as a moderator, it does not significantly strengthen the relation between IC and SCP. Our findings suggest that SMEs can acquire tangible and intangible resources through top management capabilities. For instance, Jiang et al. [8] concluded that senior management entrepreneurial abilities enable them to acquire external resources 
that in turn affect financial performance. This research argues that financially literate managers are more capable of accessing unique, rare, and immutable resources as compared to limited financial management skills [55]. Additionally, we also confirmed the prominent role of business experience in acquiring external resources. Similar results have been derived by Reimer et al. [74], who hypothesized a significant role of business experience in scanning external environmental pressure and observing useful resources. Overall, we affirm that intangible skills enable firms to access scarce resources that are necessary for SCP. Business experience significantly boosts resource acquisition and strengthens the path between IC and SCP substantially.

\subsection{Contributions of This Study}

Based on the RBV and upper echelon theory, this study examines the role of top management intangible skills and capabilities in SCP. However, prior studies have discussed a variety of factors (such as networking, financial capacity, IT capabilities, entrepreneurial orientation, dynamic capabilities, etc.) in the success and performance of SMEs (e.g., $[8,9,18])$. However, this research targets the under-discussed zone, e.g., intangible skills such as IC, financial literacy, and business experience toward resource acquisition and SCP. More precisely, this research examines the influence of IC on SCP and whether resource acquisition mediates the relation. Moreover, we also checked the moderating role of financial literacy and business experience between IC and resource acquisition. We favor the theme of RBV theory by examining the intangible resources of a firm and found that unique resources can lead to a sustainable competitive advantage over other firms [2]. Our research also supports upper echelon theory in terms of top management skills such as IC, financial literacy, and business experience that are crucial for managing resources and gaining high performance.

This research enables the Small and Medium Enterprises Authority (SMEDA) - a authority responsible for SMEs in Pakistan-to modify their internal policies and strategies to support SMEs in acquiring useful tangible and intangible resources. For instance, Anwar and Shah [1] reported that more than $50 \%$ of firms fail in the initial stage due to a lack of resources and support. The high failure ratio behooves the SMEDA and other responsible authorities to provide adequate resources to SMEs, which in turn will contribute to economic performance and employment.

\subsection{Implications}

Our research shows that IC — being an intangible factor-facilitates SMEs in accessing rare, unique, and immutable external resources that boost financial performance. Top management in emerging economies needs to be intellectual to acquire scarce resources. Compared to other skills and resources, IC is deemed less expensive and convenient [18] and can affect firms' performance. Hence, firms, especially SMEs, are required to focus on IC instead of emphasizing expensive resources. In addition to IC, business experience also significantly enriches resource acquisition and SCP. Firms are advised to retain experienced managers who can help in accessing useful means. For instance, it is argued that firms' competitiveness and economic performance can be enhanced through top management's intellectual and social abilities. However, experience is considered an excellent factor in strengthening the relation efficiently [75]. Our results show that financial literacy can significantly influence resource acquisition, but the moderating role of financial literacy between IC and resource acquisition is not significant. Considering the direct role of financial literacy, we recommend financial training, seminars, and workshops to be arranged for the top management team to improve their financial skills. Especially, managers in Pakistan need adequate financial skills to improve their firms' operational activities and resources so as to gain high profit.

\subsection{Limitations and Future Research Direction}

The results of this research are based on cross-sectional data and are constrained to a snapshot in time. This limitation can be addressed through longitudinal data sets in future research. Similarly, the results are confined to the emerging market in Pakistan only, while the collection of data from other 
emerging markets (especially China) can provide useful insights to SMEs. A structured questionnaire that is used in this research restricts respondents to given options. We recommend a qualitative approach or an interview-based study to ask open-ended questions in future studies that can provide unexplored insights. Looking at our research model, we tested the role of IC instead of each dimension, e.g., human capital, relational capital, and structural capital, in resource acquisition that can give beneficial outputs. However, RBV theory [2] states the role of both tangible and intangible resources in firms' competitive advantage. For the parsimonious reason, we also recommend the role of IC in accessing physical and intangible external resources. Additionally, we only tested specific intangible skills: IC, financial literacy, and business experience in this research. However, other intangible skills and resources, such as knowledge sharing, industry information, and decision-making ability, can be tested in this perspective. We recommend testing the role of intangible skills separately in the acquisition of external tangible and intangible resources. Lastly, the tangible skills of top managers that have remained out of focus in this research can be considered in future studies to discover which types of intangible and physical resources are crucial for venture success.

Author Contributions: H.H. has developed the model and has written the original draft. Q.Y. has reviewed the paper and has made necessary contribution e.g., supervised the paper. H.A. has helped in data collection and analysis.

Funding: This work was supported by the National Science Foundation of China [71373167], Youth Fund Project of Humanities and social sciences of the Ministry of Education in China (18YJC790204), Social Science Key Project of Sichuan Province of China (SC18A006), the Soft Science Foundation Project of Sichuan Province of China (2017ZR0191) and the research fund from Sichuan University (SKSYL201822, 2018hhf-47, skqx201608, 2013SCU04A32).

Conflicts of Interest: The authors declare no conflict of interest.

\section{References}

1. Anwar, M.; Ali Shah, S.Z. Managerial Networking and Business Model Innovation: Empirical Study of New Ventures in an Emerging Economy. J. Small Bus. Entrep. 2018. [CrossRef]

2. Barney, J. Firm resources and sustained competitive advantage. J. Manag. 1991, 17, 99-120. [CrossRef]

3. Degong, M.; Ullah, F.; Khattak, M.; Anwar, M. Do International Capabilities and Resources Configure Firm's Sustainable Competitive Performance? Research within Pakistani SMEs. Sustainability 2018, 10, 4298. [CrossRef]

4. Khan, S.Z.; Yang, Q.; Waheed, A. Investment in intangible resources and capabilities spurs sustainable competitive advantage and firm performance. Corp. Soc. Responsib. Environ. Manag. 2018. [CrossRef]

5. Paeleman, I.; Vanacker, T. Less is more, or not? On the interplay between bundles of slack resources, firm performance and firm survival. J. Manag. Stud. 2015, 52, 819-848. [CrossRef]

6. Devigne, D.; Vanacker, T.; Manigart, S.; Paeleman, I. The role of domestic and cross-border venture capital investors in the growth of portfolio companies. Small Bus. Econ. 2013, 40, 553-573. [CrossRef]

7. Spithoven, A.; Teirlinck, P. Internal capabilities, network resources and appropriation mechanisms as determinants of R\&D outsourcing. Res. Policy 2015, 44, 711-725.

8. Jiang, X.; Liu, H.; Fey, C.; Jiang, F. Entrepreneurial orientation, network resource acquisition, and firm performance: A network approach. J. Bus. Res. 2018, 87, 46-57. [CrossRef]

9. Anwar, M.; Rehman, A.U.; Shah, S.Z.A. Networking and new venture's performance: Mediating role of competitive advantage. Int. J. Emerg. Mark. 2018, 13, 998-1025. [CrossRef]

10. Franco, M.; Haase, H.; Magrinho, A.; Ramos Silva, J. Scanning practices and information sources: An empirical study of firm size. J. Enterp. Inf. Manag. 2011, 24, 268-287. [CrossRef]

11. Cai, L.; Hughes, M.; Yin, M. The relationship between resource acquisition methods and firm performance in Chinese new ventures: The intermediate effect of learning capability. J. Small Bus. Manag. 2014, 52, 365-389. [CrossRef]

12. Campbell, J.M.; Park, J. Internal and external resources of competitive advantage for small business success: Validation across family ownership. Int. J. Entrep. Small Bus. 2016, 27, 505-524. [CrossRef] 
13. Murray, A.M.; Hallen, B.L.; Kotha, S.B. Withholding signals of experience and expertise in resource acquisition efforts via crowdfunding. In Academy of Management Proceedings; Academy of Management: Briarcliff Manor, NY, USA, 2018; p. 18518.

14. Hambrick, D.C.; Mason, P.A. Upper echelons: The organization as a reflection of its top managers. Acad. Manag. Rev. 1984, 9, 193-206. [CrossRef]

15. Hussinki, H.; Kianto, A.; Vanhala, M.; Ritala, P. Happy Employees Make Happy Customers: The Role of Intellectual Capital in Supporting Sustainable Value Creation in Organizations. In Intellectual Capital Management as a Driver of Sustainability; Springer: Berlin/Heidelberg, Germany, 2019; pp. 101-117.

16. Anwar, M.; Shah, S.Z.A.; Khan, S.Z. The role of personality in SMEs internationalization: Empirical evidence. Rev. Int. Bus. Strategy 2018, 28, 258-282. [CrossRef]

17. Songling, Y.; Ishtiaq, M.; Anwar, M.; Ahmed, H. The role of government support in sustainable competitive position and firm performance. Sustainability 2018, 10, 3495. [CrossRef]

18. Anwar, M.; Khan, S.Z.; Khan, N.U. Intellectual Capital, Entrepreneurial Strategy and New Ventures Performance: Mediating Role of Competitive Advantage. Bus. Econ. Rev. 2018, 10, 63-93. [CrossRef]

19. Pinto, V.L.; Tomé, E. What is the relationship between tax literacy and intellectual capital of the certified accountant in Portuguese SMEs tax performance? In Proceedings of the International Conference on Theory and Applications in the Knowledge Economy, Zagreb, Croatia, 12-14 July 2017; pp. 323-327.

20. Januškaitè, V.; Užienè, L. Intellectual Capital as a Factor of Sustainable Regional Competitiveness. Sustainability 2018, 10, 4848. [CrossRef]

21. Xu, J.; Wang, B. Intellectual Capital, Financial Performance and Companies' Sustainable Growth: Evidence from the Korean Manufacturing Industry. Sustainability 2018, 10, 4651. [CrossRef]

22. Kamukama, N.; Sulait, T. Intellectual capital and competitive advantage in Uganda's microfinance industry. Afr. J. Econ. Manag. Stud. 2017, 8, 498-514. [CrossRef]

23. Ozkan, N.; Cakan, S.; Kayacan, M. Intellectual capital and financial performance: A study of the Turkish Banking Sector. Borsa Istanb. Rev. 2017, 17, 190-198. [CrossRef]

24. Phusavat, K.; Comepa, N.; Sitko-Lutek, A.; Ooi, K.-B. Interrelationships between intellectual capital and performance: Empirical examination. Ind. Manag. Data Syst. 2011, 111, 810-829. [CrossRef]

25. Agostini, L.; Nosella, A.; Filippini, R. Does intellectual capital allow improving innovation performance? A quantitative analysis in the SME context. J. Intellect. Cap. 2017, 18, 400-418. [CrossRef]

26. Wang, Q.; Huo, B. The Effect of Intellectual Capital on Supply Chain Integration and Competitive Performance. In Academy of Management Proceedings; Academy of Management: Briarcliff Manor, NY, USA, 2018; p. 18643.

27. Chen, F.-W.; Lin, M.-X.; Wang, T. Sustainable Resource Acquisition Path: A Dynamic Model of Embedded Entrepreneurial Network Governance under Uncertainty. Sustainability 2018, 10, 4061. [CrossRef]

28. Zhao, S.; Morgan, S. Business to Government Networks in Resource Acquisition: The Case of Chinese Private Enterprises. In Business Networks in East Asian Capitalisms; Elsevier: Amsterdam, The Netherlands, 2017; pp. 69-91.

29. Díaz-Fernández, M.C.; González-Rodríguez, M.R.; Simonetti, B. Top management team's intellectual capital and firm performance. Eur. Manag. J. 2015, 33, 322-331. [CrossRef]

30. Dalziel, T.; Gentry, R.J.; Bowerman, M. An integrated agency-resource dependence view of the influence of directors' human and relational capital on firms' R\&D spending. J. Manag. Stud. 2011, 48, 1217-1242.

31. Du, J.; Guariglia, A.; Newman, A. Do Social Capital Building Strategies Influence the Financing Behavior of Chinese Private Small and Medium-Sized Enterprises? Entrep. Theory Pract. 2015, 39, 601-631. [CrossRef]

32. Li, Y.-Q.; Liu, C.-H.S. The role of problem identification and intellectual capital in the management of hotels' competitive advantage-an integrated framework. Int. J. Hosp. Manag. 2018, 75, 160-170. [CrossRef]

33. Otcenášková, T.; Bureš, V. Self-assessment of intellectual capital in an organisation: Inclusion of internal view, dynamics, and topicality. J. Intellect. Cap. 2018, 19, 387-406. [CrossRef]

34. Skirnevskiy, V.; Bendig, D.; Brettel, M. The influence of internal social capital on serial creators' success in crowdfunding. Entrep. Theory Pract. 2017, 41, 209-236. [CrossRef]

35. Cabrilo, S.; Dahms, S. How strategic knowledge management drives intellectual capital to superior innovation and market performance. J. Knowl. Manag. 2018, 22, 621-648. [CrossRef] 
36. Laud, G.; Karpen, I.O.; Mulye, R.; Rahman, K. The role of embeddedness for resource integration: Complementing SD logic research through a social capital perspective. Mark. Theory 2015, 15, 509-543. [CrossRef]

37. Lee, R.; Tuselmann, H.; Jayawarna, D.; Rouse, J. Effects of structural, relational and cognitive social capital on resource acquisition: A study of entrepreneurs residing in multiply deprived areas. Entrep. Reg. Dev. 2018. [CrossRef]

38. Akhtar, P.; Khan, Z.; Frynas, J.G.; Tse, Y.K.; Rao-Nicholson, R. Essential micro-foundations for contemporary business operations: Top management tangible competencies, relationship-based business networks and environmental sustainability. Br. J. Manag. 2018, 29, 43-62. [CrossRef]

39. Sachitra, V.; Chong, S.-C. Resources, capabilities and competitive advantage of minor export crops farms in Sri Lanka: An empirical investigation. Compet. Rev. Int. Bus. J. 2018, 28, 478-502. [CrossRef]

40. Haji, A.A.; Mohd Ghazali, N.A. The role of intangible assets and liabilities in firm performance: Empirical evidence. J. Appl. Account. Res. 2018, 19, 42-59. [CrossRef]

41. Barney, J.B.; Arikan, A.M. The resource-based view: Origins and implications. Handb. Strateg. Manag. 2001, 124188. [CrossRef]

42. Shane, S.A. A General Theory of Entrepreneurship: The Individual-Opportunity Nexus; Edward Elgar Publishing: Cheltenham, UK, 2003.

43. Jordão, R.V.D.; Novas, J.C. Knowledge management and intellectual capital in networks of small-and medium-sized enterprises. J. Intellect. Cap. 2017, 18, 667-692. [CrossRef]

44. Liu, C.-H. Creating competitive advantage: Linking perspectives of organization learning, innovation behavior and intellectual capital. Int. J. Hosp. Manag. 2017, 66, 13-23. [CrossRef]

45. Kamukama, N.; Kyomuhangi, D.S.; Akisimire, R.; Orobia, L.A. Competitive advantage: Mediator of managerial competence and financial performance of commercial banks in Uganda. Afr. J. Econ. Manag. Stud. 2017, 8, 221-234. [CrossRef]

46. Song, Z.-F. The Relationship among Top Managerial Social Capital, Resource Acquisition and the Growth Performance of Small and Medium-sized Travel Agencies. In Proceedings of the 2018 International Conference on Internet and e-Business, Singapore, 25-27 April 2018; pp. 218-222.

47. Kianto, A.; Ritala, P.; Spender, J.-C.; Vanhala, M. The interaction of intellectual capital assets and knowledge management practices in organizational value creation. J. Intellect. Cap. 2014, 15, 362-375. [CrossRef]

48. Fernandes, D.; Lynch, J.G., Jr.; Netemeyer, R.G. Financial literacy, financial education, and downstream financial behaviors. Manag. Sci. 2014, 60, 1861-1883. [CrossRef]

49. Yang, S.; Ishtiaq, M.; Anwar, M. Enterprise Risk Management Practices and Firm Performance, the Mediating Role of Competitive Advantage and the Moderating Role of Financial Literacy. J. Risk Financ. Manag. 2018, $11,35$.

50. Foley, J. We really need to talk about owner-managers and financial awareness! Small Enterp. Res. 2018, 25, 90-98. [CrossRef]

51. Cole, S.; Paulson, A.; Shastry, G.K. Smart money? The effect of education on financial outcomes. Rev. Financ. Stud. 2014, 27, 2022-2051. [CrossRef]

52. Badolato, P.G.; Donelson, D.C.; Ege, M. Audit committee financial expertise and earnings management: The role of status. J. Account. Econ. 2014, 58, 208-230. [CrossRef]

53. Hussain, J.; Salia, S.; Karim, A. Is knowledge that powerful? Financial literacy and access to finance: An analysis of enterprises in the UK. J. Small Bus. Enterp. Dev. 2018, 25, 985-1003. [CrossRef]

54. Carbó-Valverde, S.; Rodríguez-Fernández, F.; Udell, G.F. Trade credit, the financial crisis, and SME access to finance. J. Money Credit Bank. 2016, 48, 113-143. [CrossRef]

55. Fraser, S.; Bhaumik, S.K.; Wright, M. What do we know about entrepreneurial finance and its relationship with growth? Int. Small Bus. J. 2015, 33, 70-88. [CrossRef]

56. Dittmar, A.; Duchin, R. Looking in the rearview mirror: The effect of managers' professional experience on corporate financial policy. Rev. Financ. Stud. 2015, 29, 565-602. [CrossRef]

57. Libby, R.; Rennekamp, K.M. Experienced financial managers' views of the relationships among self-serving attribution bias, overconfidence, and the issuance of management forecasts: A replication. J. Financ. Rep. 2016, 1, 131-136. [CrossRef] 
58. Matemilola, B.; Bany-Ariffin, A.; Azman-Saini, W.; Nassir, A.M. Does top managers' experience affect firms' capital structure? Res. Int. Bus. Financ. 2018, 45, 488-498. [CrossRef]

59. von den Driesch, T.; Da Costa, M.E.S.; Flatten, T.C.; Brettel, M. How CEO experience, personality, and network affect firms' dynamic capabilities. Eur. Manag. J. 2015, 33, 245-256. [CrossRef]

60. Li, P.-Y. Top management team characteristics and firm internationalization: The moderating role of the size of middle managers. Int. Bus. Rev. 2018, 27, 125-138. [CrossRef]

61. Schaltenbrand, B.; Foerstl, K.; Azadegan, A.; Lindeman, K. See what we want to see? The effects of managerial experience on corporate green investments. J. Bus. Ethics 2018, 150, 1129-1150. [CrossRef]

62. Custódio, C.; Metzger, D. Financial expert CEOs: CEO's work experience and firm's financial policies. J. Financ. Econ. 2014, 114, 125-154. [CrossRef]

63. Bontis, N.; Chua Chong Keow, W.; Richardson, S. Intellectual capital and business performance in Malaysian industries. J. Intellect. Cap. 2000, 1, 85-100. [CrossRef]

64. Maditinos, D.; Chatzoudes, D.; Tsairidis, C.; Theriou, G. The impact of intellectual capital on firms' market value and financial performance. J. Intellect. Cap. 2011, 12, 132-151. [CrossRef]

65. Chahal, H.; Bakshi, P. Examining intellectual capital and competitive advantage relationship: Role of innovation and organizational learning. Int. J. Bank Mark. 2015, 33, 376-399. [CrossRef]

66. Han, Y.; Li, D. Effects of intellectual capital on innovative performance: The role of knowledge-based dynamic capability. Manag. Decis. 2015, 53, 40-56. [CrossRef]

67. Wise, S. The impact of financial literacy on new venture survival. Int. J. Bus. Manag. 2013, 8, 30. [CrossRef]

68. Adomako, S.; Danso, A.; Ofori Damoah, J. The moderating influence of financial literacy on the relationship between access to finance and firm growth in Ghana. Ventur. Cap. 2016, 18, 43-61. [CrossRef]

69. Bernt, M.; Donath, A.; Jühling, F.; Externbrink, F.; Florentz, C.; Fritzsch, G.; Pütz, J.; Middendorf, M.; Stadler, P.F. MITOS: Improved de novo metazoan mitochondrial genome annotation. Mol. Phylogenet. Evol. 2013, 69, 313-319. [CrossRef] [PubMed]

70. Mestry, R. The role of governing bodies in the management of financial resources in South African no-fee public schools. Educ. Manag. Adm. Leadersh. 2018, 46, 385-400. [CrossRef]

71. Mohamed, E.B.; Jarboui, S.; Baccar, A.; Bouri, A. On the effect of CEOs' personal characteristics in transport firm value? A stochastic frontier model. Case Stud. Transp. Policy 2015, 3, 176-181. [CrossRef]

72. Ko, E.-J.; McKelvie, A. Signaling for more money: The roles of founders' human capital and investor prominence in resource acquisition across different stages of firm development. J. Bus. Ventur. 2018, 33, 438-454. [CrossRef]

73. Grilli, L.; Murtinu, S. Selective subsidies, entrepreneurial founders' human capital, and access to R\&D alliances. Res. Policy 2018, 47, 1945-1963.

74. Reimer, M.; Van Doorn, S.; Heyden, M.L. Unpacking functional experience complementarities in senior leaders' influences on CSR strategy: A CEO-Top management team approach. J. Bus. Ethics 2018, 151, 977-995. [CrossRef]

75. Hernández-Carrión, C.; Camarero-Izquierdo, C.; Gutiérrez-Cillán, J. Entrepreneurs' Social Capital and the Economic Performance of Small Businesses: The Moderating Role of Competitive Intensity and Entrepreneurs' Experience. Strateg. Entrep. J. 2017, 11, 61-89. [CrossRef]

76. Anwar, M. Business model innovation and smes performance-Does competitive advantage mediate? Int. J. Innov. Manag. 2018, 1850057. [CrossRef]

77. Okello Candiya Bongomin, G.; Mpeera Ntayi, J.; Munene, J.C.; Akol Malinga, C. The relationship between access to finance and growth of SMEs in developing economies: Financial literacy as a moderator. Rev. Int. Bus. Strategy 2017, 27, 520-538. [CrossRef]

78. Hair, J.F.; Anderson, R.E.; Babin, B.J.; Black, W.C. Multivariate Data Analysis: A Global Perspective; Pearson: Upper Saddle River, NJ, USA, 2010; Volume 7.

79. Hu, L.T.; Bentler, P.M. Cutoff criteria for fit indexes in covariance structure analysis: Conventional criteria versus new alternatives. Struct. Equ. Model. Multidiscip. J. 1999, 6, 1-55. [CrossRef]

80. Nunnally, J.C.; Bernstein, I. Psychometric Theory (McGraw-Hill Series in Psychology); McGraw-Hill: New York, NY, USA, 1994; Volume 3. 
81. Podsakoff, P.M.; Organ, D.W. Self-reports in organizational research: Problems and prospects. J. Manag. 1986, 12, 531-544. [CrossRef]

82. Klapper, L.; Lusardi, A.; Van Oudheusden, P. Financial Literacy Around the World; Global Financial Literacy Survey: Washington, DC, USA, 2015.

(c)

(c) 2019 by the authors. Licensee MDPI, Basel, Switzerland. This article is an open access article distributed under the terms and conditions of the Creative Commons Attribution (CC BY) license (http:/ / creativecommons.org/licenses/by/4.0/). 